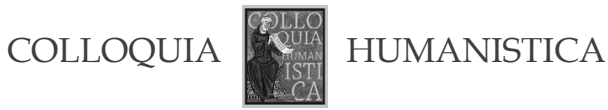

\title{
Dechka Chavdarova
}

\author{
Department of History and Theory of Literature, \\ Faculty of Humanities \\ Konstantin Preslavsky University of Shumen \\ Shumen \\ d.tchavdarova@gmail.com
}

\section{Limes Slavicus: A Project of the Department of History and Theory of Literature at Konstantin Preslavsky University of Shumen (Bulgaria)}

\begin{abstract}
The text presents the three volumes of the Limes Slavicus series (Enchev, 2016; Kristeva, 2017; Tsanov, 2018) of the Faculty of Humanities at Konstantin Preslavsky University of Shumen. It gives an idea of the main concepts of the articles featured in the issues, while putting forth the question of what the "Slavic cultural concept" means as a notion, and discussing the problems facing research of the Slavic cultural community (the danger of ideologization, the "Slavification" of universal concepts).

Keywords: cultural concept, Slavic idea, Slavdom, boundaries of Slavdom.

The idea of Slavdom as a cultural community re-emerges at different historical stages due to various political and cultural factors. At the same time, this idea periodically turns problematic because of certain political, religious and mentality conflicts among Slavic peoples. In our time it has become prevalent in the changed geopolitical situation, in which individual Slavic countries find themselves in different cultural, political,

This is an Open Access article distributed under the terms of the Creative Commons Attribution 3.0 PL License (creativecommons.org/licenses/by/3.0/pl/), which permits redistribution, commercial and non-commercial, provided that the article is properly cited. (c) The Author(s), 2019.

Publisher: Institute of Slavic Studies, Polish Academy of Sciences

Editor-in-chief: Jolanta Sujecka

Conception and academic editing of this issue: Katarzyna Roman-Rawska, Tomasz Rawski
\end{abstract}


military alliances. The "Slavic idea" is useful politically but also of interest to scholars from different fields of the humanities (cultural studies scholars, ethnologists, literary researchers, linguists, historians). One of the dangers these researchers are facing is ideology, apology of the idea itself, instead of studying it with the necessary scientific distance. Another important issue faced by the organizers of scientific forums and compilers and editors of volumes on the subject is the interpretation of what is meant by the notion of "Slavic idea" or "Slavic cultural concept": often along with texts that examine the history of the "Slavic idea", similarities and differences between Slavic languages and cultures, there are also texts about problems of individual Slavic cultures. However, existing institutions of Slavic Studies are concerned with the study of individual Slavic cultures, although they also apply the contrastive method, seeking common features between the cultures and national mentalities of Slavic peoples. Moreover, when examining the cultural concepts of Slavdom, it is rarely discussed whether certain concepts are specific to the entire Slavic cultural community or only to certain Slavic cultures, whether they are Slavic or universal (biblical, mythological, etc.).

Limes Slavicus is part of the title of a project of the Department of History and Theory of Literature at Konstantin Preslavsky University of Shumen and clearly points to the idea of its authors: to outline the boundaries of the Slavic cultural community. This expression is also present in the titles of the three volumes published on the basis of the project I present here. The first volume includes two sections: "Linguistics" and "Literary Studies". The University of Presov (Slovakia) was a co-organizer of the international scientific conference at which the texts included in the volume were presented. Therefore, some of the articles in the "Linguistics" section outline Slovak-Bulgarian or SlovakRussian language parallels: D. Daskalova and R. Chapak analyse particles in Slovak and Bulgarian, again raising the important problem of comparative linguistics - "the identity and differences in the kinship languages"; N. Nikolov examines prepositional constructions in Slovak and Bulgarian, also explaining both equivalence and "linguistic asymmetry", but from the point of view of foreign language learning; the context of foreign language learning is also presented in the article by D. Sabolova and V. Kosova devoted to the problem of inter-Slavic language interference in teaching Russian as a foreign language; the phenomenon of interference is also addressed by L. Zaynalova, but she analyses an example of bilingualism in which the Slavic (Russian) and non-Slavic (Lezgian) language interact in the learner's speech. D. Antonyakova compares phraseological units containing the chromonym "blue" in Slovak and Russian, drawing from them the connotations/symbolism of the words siniy 'blue' and goluboy 'azure'. This type of comparative research raises the question whether the open connotations of the word are inherent in other 
Slavic languages besides the two that the authors compare. N. Nikolova's article compares not two Slavic languages but two manifestations of a linguistic idea - Slovak and Bulgarian linguistic purism (I will emphasize the author's view that "the parallels are mainly necessary to highlight the specifics" [Enchev, 2016, p. 31]). The comparative study by N. Kravchenko discusses the problem of linguistic culture (pseudo-non-acceptance of a compliment) in Russian and Ukrainian culture, implicitly suggesting a similarity in the national mentality of the two nations. This case again begs the question whether such a feature is inherent in other Slavic and not only Slavic cultures. Important issues of the Slavic cultural community are discussed in J. Dudášová-Krišáková's article "Slovanské spisovné mikrojazyky" (Standard Slavonic Micro-languages), whose focus is on the languages of the so-called "Rusyns" inhabiting a territory foreign to the Slavic language, and in the article by A. Tihova, who considers the Slavonic translation of the History of the Jewish War by Flavius, discusses an unclarified scientific problem and considers the role of Slavonic texts written in medieval Bulgaria (in the time of Tsar Simeon) in other Slavic cultures. The section also includes an article by G. Koneczniak, meta-scientific in character, which presents Slavic Studies journals in order to put forward the significant scientific problem of the scope of the term Slavistics and the editorial policy of the journals. To outline the boundaries of Slavism, the article by J. Jóźwiak uses an interesting perspective: the involvement of a third culture in the communication between two Slavic cultures. The author analyses the transfer of realms' names from American culture to the Polish translations of Akunin's works as a means of preserving signs of the exotic or their loss.

The first Limes Slavicus volume of collected papers (Enchev, 2016) is still looking for a way to study the problem of the Slavic cultural community, which explains why there are a number of texts that address issues of individual Slavic cultures: the articles by M. Kravyarova "Measuring Voice Onset Time in Slovak Stop Consonants" and V. Smolyakova "Speech Tempo Realization in Radio News Reporting", articles on Slovak adjectives (by V. Perovská), on the concept of emptiness in Russian culture (by Kaleva), on the metaphor bomzh (bum, tramp, vagrant) in connection with the image of Russia (by E. Stoyanova), the language of the Bulgarian ethnographic communities in the Shumen region (by K. Koleva), Turkish borrowings in the Bulgarian language (by A. Baeva), the names of Bulgarian malls (by R. Borowiak and A. Sierodzki), expressive lexemes in the comedies of Branislav Nušić (by V. Naidenova).

In the "Literature" section I will highlight several articles that offer a new interpretation of the Slavic idea as an ideological construct or the idea of a Slavic cultural/literary community. The article by D. Kristeva "The Slavic 
Idea in the 18th Century, Russian Imperial Ideology and the Politics of Historiography at the Time of Baroque and Classicism" analyses phenomena from the cultural and political history of Russia: sources of the "Slavic idea" in Russian culture as early as the 17th century (preceding the ideas of 19thcentury Slavophilism and Pan-Slavism) and its use in the imperial ideology of Peter I and Catherine II. In the article by Yani Milchakov, "Slavonic Literary Comparatism at the Beginning of the 21st Century (Crisis, Chance and Challenge)", the ideas of comparatism, the questioning of this scientific methodology, the search for new approaches, are redefined theoretically. From the point of view of the problem of the boundaries of Slavdom, it is very valuable to observe the issue of the present Slavic cultural affiliation in some Slavic countries, to find new approaches to Slavic comparatism (for example, the imageology that the author perceives as "therapy" or "trauma"). H. Trendafilov's article "The Hero in Man's Eucharist" interprets the transformation of a ruler's grave into a "place of memory" (by Pierre Nora), the important role of the grave in the ruler's mythologization. The author does not raise the issue of the Slavic cultural community, but the proposed comparisons between the Bulgarian, Czech, Polish and Russian cultures suggest general processes in these cultures (the phenomenon of "grave seeking" in the Slavic world). At the same time, the researcher's erudition directs us to a wider Christian context and to other, non-Slavic cultures (e.g. Hungarian). This broadening of the context presents an important problem in the study of concepts in a given culture or cultural community that I have addressed in the introductory part of my text: how specific they are to a culture/community or whether they are universal. Addressing the current problem of historical kitsch, Trendafilov also suggests another motivation for the emergence of the phenomenon of "grave seeking" beyond ethnic (Slavic) closeness - the "Reflection of the Small Peoples". D. Ivanova develops ideas about the history of the Slavic early printed books by observing the "Bulgarian Incunabula" (the first Cyrillic Slavic book) and the Renaissance role of Jacob Kraykov. In view of the boundaries of Slavdom, it is very important to conclude that "the first Bulgarian printed books are a combination of two cultures - the Bulgarian culture and the culture of the country where they were printed". A. Kraev writes about another type of interaction of two cultures - between two confessions within a Slavic culture - in his article "Beginning and Development of the Catholic Church Discourse in Russia at the End of the 20th Century and the Beginning of the 21st Century". Very important and up-to-date is the observation that "today's religion is not mixed with nationality". The author analyses similarities and differences in Orthodox and Catholic terminology, the use of the Russian language in the discourse of the Catholic Church in the genres of preaching and breve, and 
concludes that this discourse has become a part of the "general picture of the Russian literary language". A. Dimitrova focuses on the dialogue between a Slavic (Russian) and a non-Slavic (German) culture in her study of the image of Russia in the work of Hermann Hesse: "Foreign, Unknown Expanses: Hermann Hesse about Russia" (a study close to imageology, although the author does not use this term). I will emphasize that the view outside the Slavic world is very valuable for reaching the Slavic specificity. The author comments on Hesse's idea about similarities and differences between the German and the Slavic type (a problem which is, of course, a subject of interest for famous German and Russian philosophers), the German writer's view of Russia's cultural role for the renewal of Europe (corresponding to the Russian Eurasian idea). The researcher's pathos originates from the significance of the problem of intercultural dialogue in the modern world. From the text we can draw other interesting issues: the perception of the Slavic/ Russian through literature (the reading of The Brothers Karamazov), the identification of the Slavic with the Russian in the West, the notion that a sense of closeness to a culture is based not so much on an ethnic as on a cultural foundation (the perception of the Russian as his 'own kind' by Hesse's grandfather, a German from Estonia). The dialogue between Slavic and non-Slavic cultures is also addressed by V. Yankova in her article "About the Other in the Slavic Cultural Context (to the Oral History of the Tatars in Southern Dobrudja)". The author deals with the problem of the boundaries of Slavdom, going outside the framework of the specific scientific material and concludes: "The boundaries of the Slavic cultural space have their geographical, historical, cultural aspects, and their construction in time also occurs with the participation of the 'great Other' in Europe - the Muslims" (a conclusion which leads to the problem of identifying religion and ethnicity and ignoring the Slav Muslims). Another type of intercultural connection within the framework of Slavdom is considered in the article by P. Shulikov "The Fate of a Pushkin Idea in Chudomir". This text conforms to the tradition of tracing Bulgarian-Russian literary ties but offers a new perspective on them: not a search for typological or contactological closeness, but the discovery of "strange approximations" (cf. Pushkin) between works of different epochs belonging to different levels in the hierarchy of culture ("high" and "low"). The comparison between Pushkin and Chudomir is based on a parody of highbrow literary works, on the idea that "small reasons can lead to great consequences". Another connection between the two Slavic cultures is analysed in N. Nyagolova's article "Semiotics of the Object in the Theatre Spectacles of Lubomír Vajdička (Ostrovsky - Chekhov)", in which the author not only offers a semiotic reading of the play in the Slovak playwright's performances, but also questions the specificity of the 
interpretation of Russian dramaturgy in these performances, as well as the extra-artistic factors of Vajdička's directing of Russian drama after 1968.

The literary part of the collection also includes articles dealing with problems and phenomena in individual Slavic cultures (Bulgarian, Russian, Slovak) from the Middle Ages to the present day. V. Panayotov provides an insight into acrostics in Slavonic liturgical books, in which he discovers signatures of the hymnographer Boris, and hypothesises about their relation to Prince Boris I. I. Rasheva analyses the myth of Saints Cyril and Methodius' participation in the conversion of the Bulgarians, which originates in Istoriya Slavyanobulgarska (History of Slavic Bulgarians) written by Paisii and passes through the historiography of the whole Bulgarian 19th-century Revival. The text suggests that St. Cyril and St. Methodius are one of the main concepts in Bulgarian culture. S. Tsanov draws attention to another important concept of Bulgarian culture - Tsar Simeon - by referring to the work of N. Raynov Videniya iz Drevna Bulgaria (Visions from Ancient Bulgaria). G. Gilazetdinova and L. Bagmanova discuss the "spatial-temporal organization of the worldview in the work of Shmelyov Leto Gospodne (God's year)" by discovering in it elements of Slavic/Russian folk culture and Orthodox culture (the question of the boundaries of Slavism is not addressed in this case). M. Enchev turns to the work of another contemporary Russian writer: the novel Sletki by Lihanov, in order to present some problems of contemporary culture with pathos - a missing father, the crisis of the native, eternal moral values (the text also raises questions about the correlation between the Slavic and the universal).

The second volume - Limes Slavicus 2. Cultural Concepts of Slavdom (Kristeva, 2017) - is structured in a different way: the criterion for grouping the articles in the individual sections is not the scientific discipline (literary criticism, linguistics, etc.), but a certain aspect of the interpretation of the "Slavic idea".

The first section is entitled "Slavic Concepts in History and Culture" and has several subdivisions. One of them brings together articles that interpret the concept of the alphabet and the images of St. Cyril and St. Methodius as a cultural concept. An important place among them goes to the text by D. Dobrev, who makes an in-depth semiotic analysis of the Glagolitic alphabet, taking into account the education of Constantine Cyril the Philosopher, revealing the symbolism of the letters signifying Jesus, the symbolism of such elements of the letters as a circle, a solar wheel, the swastika, the cross, the symbolic numeral, and the sequence of the letters. On the basis of this analysis, the researcher affirms his main thesis that "the Glagolitic alphabet is designed as a sacred one to confirm the Orthodox cult of Jesus as a God-man" (Kristeva, 2017, p. 16). Following the same direction, G. Stoyanova finds 
topoi and proto-images containing the idea of Methodius as a Slavic saint in Prostranno zhitie na sveti Metodiy (Extensive Hagiography of St. Methodius). The term "topos" in the researcher's concept means a sustainable element of the saint's image ("God's messenger", "endowed with the gift of prophecy", "preaching among pagans") or a steady motif of the narrative. From the words of the story she derived the proto-images to which the author refers: Old Testament patriarchs and prophets, New Testament apostles and martyrs. This reading of the hagiography leads us to the question about the universal biblical conceptualization of the devisers of the Slavic alphabet, which includes the idea of the Slavic (the Slavic saint). The article by R. Todorova "The Conceptualization of the Images of St. Cyril and St. Methodius in the Iconographic Model of Nikola Vassilev from Shumen" draws attention to the transformation of the images of the "holy brothers" into a Bulgarian concept: depicting the participation of St. Methodius in the conversion of Tsar Boris I in Preslav, the image of the saints against the background of the ancient Bulgarian capital transforms the Slavic concept into a Bulgarian concept in the name of the patriotic idea during the Bulgarian 19th-century Revival. The same phenomenon, but based on literary material and a different period in the history of Bulgarian culture, is analysed by $\mathrm{M}$. Enchev in his article "Orthography of One's Own. Cyril and Methodius in the Bulgarian Primary School Reading Books and Children's Magazines of the first half of the 20th Century". Enchev's approach is notable for its critical (ironic) distance from the object of research: the author shows how the writers of children's literature turn the alphabet of the holy brothers Cyril and Methodius into an "ethnically marked zone of their own" to distinguish them from others (not only Romanians and Greeks but also Slavs like the Serbs), how after the change of the government in 1944 the alphabet was again used for other political purposes (the ideology of the Slav brothers about the letters with which Lenin and Stalin wrote). I will point out that Enchev's text was written almost at the same time as D. Naydenova's article "The Cyril-Methodius Idea and Socialist Propaganda" (Naĭdenova, 2017), which convinces us that there are certain ideas that are "floating in the air".

The second group of texts in the section "Slavic Concepts in the History of Culture" is entitled "Ethno-Political Mythology and Slavic Concepts in Language, Literature and Art". N. Nikolova compares the idea of linguistic purity in South Slavic cultures by discovering both common ideas born in a similar historico-political situation and as a result of cultural interactions, and differences ("National Revival Idea of Language Purity in Southern Slavic Nations"). A. Marinova analyses the language of the poetry of Konstantin Miladinov-aBulgarian revivalist who studied in Russia and was related to the ideas of Russian Slavophiles - and discovered the peculiarities of the Struga 
dialect. K. Okano explores verbs of visual perception in Rusyns' VojvodinaRuthenian language in the light of Slavic etymology and reaches conclusions about their common semantic roots inherited from Old Slavonic vocabulary but also about the uniqueness of their semantics. S. Sivrievs's article "Slavic Identity at the Time of the Bulgarian National Revival (Hristofor Žefarovićs Stematografia and the Deacon's Gates in Rila Monastery)" introduces the images of the deacon's doors in the Church of the Nativity of the Virgin at Rila Monastery, made by Nikola Obrazopisov, who combines icons of Jesus Christ and St. Cyril and St. Methodius with the coats of arms of Slavic countries (Serbia, Bosnia, Russia, Montenegro) and Wallachia, Moldova. The author concludes that the creation of this iconostasis presents "the ideal time and space for the Slavic states", the notion of Slavic grandeur, but also the convergence of "earthly and heavenly, holiness and history". The article by P. Panayotov "Vazov's Long-suffering Genevieve" engages us in an interesting research storyline in which the author searches with archaeological passion for the sources of the text of the play Long-suffering Genevieve whose performance by an amateur Bulgarian theatre during the Revival Vazov depicts. Following B. Penev's findings on the source of this text - Pavel Todorov's translation from 1851 from the Serbian translation of a German dramatization of a short novel by Johann Christoph Schmidt Panayotov collected rich material from German literature to illustrate why Serbia and Bulgaria did not reach for the works of Ludwig Tieck, Friedrich Müller, Friedrich Hebel, which points to the receptive horizon of the audience in these countries. (The fact that a German novel is translated from Serbian into Bulgarian also reveals the role of Serbian culture as a mediator culture.) Based on his observations on the intertwining of the comic with the tragic in the world of Vazov's novel (and in the Bulgarian reality of the 19th century), Panayotov concludes that "Bulgaria is crucified between historical comedy and historical tragedy, the heroine Genevieve is identified with the image of long-suffering Bulgaria during the Revival" (Kristeva, 2017, p. 182). Thus, the concept of long-suffering is conceived not only as a Slavic transformation of the universal biblical concept of Job, but also as a specific Bulgarian concept. D. Chavdarova also focuses on the Slavic specificity of the universal biblical concept of long-suffering, relying on the common word

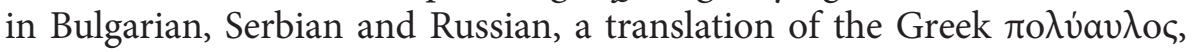
but emphasizes the Russian characteristics of this concept. Observations of various texts of Russian culture (historiographical, literary, and journalistic) allow us to derive sustainable connotations of Russian conceptualization of long-suffering: the multiple sources of suffering, the Russian people's need for suffering, waiting for God's salvation and recognition of their longsuffering by the others. 
The third section is entitled "The Slavic Question: Concepts and Ideological Narratives”. P. Káša’s article presents the Slovak idea of Slavic unity introduced by Ján Kollár, Pavel Jozef Šafárik and Ludovít Štúr as a political utopia. This idea has been of interest to researchers since its appearance, but in every new age it has been re-interpreted from the point of view of new ideas in the humanities, thus keeping it alive. R. Ilcheva's article "The Predecessor of Slavophiles - S. N. Glinka: Strokes to His Portrait" introduces the reader to the Russian writer, publisher and publicist Glinka, taking into account the fact that he is a "familiar stranger" and involves the reader in finding out "Why?". The answer is found in the specifics of Glinka's patriotic ideas, in rewriting Russian history with a patriotic purpose (this generates associations with modern times, supported in the article with the "revival" of interest in Glinka today). The connection to the volume's title, Cultural Concepts of Slavdom, is Glinka's observation on the idea of Slavic brotherhood, preceding Pan-Slavism. E. Annenkova addresses another significant manifestation of the Slavic idea - the work of Russian Slavophiles ("The Slavic Question in the Understanding of the Slavophiles of 1840-1850: Journalistic and Poetic Discourses"). The article corresponds to the research context of increased interest in the Slavophiles of our time, motivated by the contemporary Russian national ideology. The author does not only address texts that have not been sufficiently researched, but also offers her assessment of Russian Slavophilism. The journalistic and poetic texts of Russian Slavophiles, in Annenkova's view, contain the "ideal historical and cultural image" whose essence is the notion of "brotherhood" (Kristeva, 2017, p. 231). O. Timanova goes in the same direction in her article "The Idea of Slavic Reciprocity in Alexander Veltman's Tale Trayan and Angelitsa: Representation of Embodiment". In the poem Trayan and Angelitsa by Veltman, the author discovers general Slavic mythological motifs and images and brings the Russian writer closer to Jan Kolar in his ambition to "put an end to the oblivion of Slavic symbolism". S. Tsanov's article considers the famous book by Venelin, The Old and Today's Bulgarians..., in the light of modern theories about the relationship between science and ideology. The author points to historical facts as well as violations of scientific truth, exaggeration and hyperbolization, and the "Russification" of the Bulgarians. The author emphasises that both scientific truth and mythologization serve Bulgarian Revival ideology. M. Nyagolova "revives" texts with a Slavophile orientation from a Bulgarian journal from the 1920s, Slavonic Voice: "Slavophile Ideas in Bulgaria in the 1920s (Based on Publications in Slavonic Voice Review)". The researcher shows the transformation of the Slavic idea in various historical and political periods, the problems with this idea as a result of conflicts between individual 
Slavic countries, reaching the conclusion of neo-Slavism in the 1920s, the rejection of pan-Slavism, and affirmation of the free communication of Slavic peoples regardless of the political government in their countries (a conclusion that has utopian elements). A. Balcheva gives an overview of "Truths and Mystifications in the Discourse of Slavicity in Central Europe and the Balkans". The text is directly related to the topic of the boundaries of Slavdom, as it sheds light on the issue of the centres and peripheries of Slavic cultures (Slavic versus Balkan, German, Hungarian versus Slavic, Italian versus Slavic, Balkan versus German). The author considers the metamorphoses of the Slavic idea in various Slavic countries (the Illyrian movement, pan-Slavism, Polish Messianism, Czech philological Slavism, Bulgarian Slavophilism/Russophilism) in the context of the postmodern era's ideas for new centres and peripheries or Anderson's concept of imagined communities.

The last section of the collection is entitled "Images and Artefacts of the Slavs in Intercultural Communication". A. Vacheva's article "The Philosophe Champêtre's Illusions about Russia: Catherine the Great's Policies in the 1760s through the Eyes of Valentin Jameray Duval (1695 - 1775)" conforms to the contemporary scientific tendency to study marginal, non-canonical texts of culture, and in particular the genre of personal correspondence, with regard to "structures of everyday life" and intercultural communication. In Duval's (philosophe champetre's) letters to a maid of honour, Anastasia Sokolova, the researcher discovers the image of Catherine the Great as an embodiment of the Enlightenment ideal. H. Mevsim's article is the result of his own study of the library collection of the seminary on Halki Island in the Sea of Marmara, aimed at discovering and systematizing the Cyrillic books there. This bibliographic research focuses on the functioning of Slavic language texts in another culture. D. Chavdarova's article analyses the conceptualization of Bulgarian-Russian linguistic closeness in 20th-century Russian poetry, which leads her to the mythologeme and ideologemes of the Russian-Bulgarian brotherhood in the poetic image of Bulgaria (the poetic etymology of Bulgarian names, the idea of unnecessary translation and of overcoming linguistic differences through love, emphasizing the common vocabulary and common roots of the two languages).

The volume Limes Slavicus 3. Cultural Concepts of Slavdom (Tsanov, 2018) is divided into three sections: "Language: Cultural and Literary Contexts", "Ideology" and "Art".

The first section includes articles of linguo-cultural studies comparing the connotations of a particular concept in two Slavic cultures and articles on comparative Slavic linguistics. D. Konstantinova analyses the concept of wine in Slovak and Bulgarian idioms and proverbs, finding many similar 
meanings but also features specific to each culture. Since the concept of wine is universal (with roots in antiquity and Christian culture), the question of what is specifically Slavic in its semantic content arises. Another concept in two Slavic cultures is examined in I. Panchev's article "Traces of the Concept of Money in Two Slavic Linguistic Cultures (Bulgarian and Russian)". The author offers a historical overview of money's first appearance as a means of exchange and an etymological overview of the origin of the word money, more specifically the Bulgarian word pari and the Russian word den'gi (I will point out here that the Persian and Mongolian origin of these words suggests a closeness between Russian and Bulgarian culture that is not based on Slavic kinship but on their contacts with Eastern cultures). The researcher draws the semantics of the words pari and den'gi from Bulgarian and Russian proverbs, emphasizing the specifics of the genre: the embodiment of the collective experience, which is not unambiguous when evaluating money. Since the examples show similar semantics, the question of what the specificity is of each culture remains unanswered. The Russian conceptualization of money (trader, wealth) can be interpreted in a broader view on Russian culture (especially on literature) that has found its place in the scientific sources. P. Borowiak and A. Sierodzki consider highbrow, religious culture, and especially the conceptualization of Sunday in the "Bulgarian Orthodox liturgical calendar and the Polish Catholic liturgical calendar", following the history of Sundays being perceived as the "basis of the order of the liturgical calendar" which symbolizes a "cyclically repeated complex of events related to the history of Salvation". The indepth comparative analysis of the Bulgarian Orthodox calendar with the Polish Catholic calendar shows similarities in the two congregations as well as differences: three points of spatial arrangement in the Orthodox calendar (Easter, Pentecost and the Elevation of the Holy Cross) and identifying Sundays by a locative phrase (and sometimes by a name), and choosing one point of order (Easter), eliminating the locative phrase from the Catholic calendar. The authors do not thematize the problem of the boundaries of Slavism, but their observations suggest the language community of the two Slavic cultures and confessional differences between them, which is to some extent problematic for the Slavic community. In his article "Slavic Verbs of Underwater Motion: Parallels and Divergences", Slavic scholar K. Okano is interested in another type of similarity between Slavic cultures: linguistic closeness based on a common Slavic root, as well as semantic differences between the same lexemes. A similar perspective is presented in T. Balek's article "The Perception of Reality as Presented with the Use of the Temperature Adjectives hladan in Serbian and holodniy in Russian". The observations on the Serbian word hladan and the Russian holodniy 
show the closeness between the Russian and Serbian languages, the use of the words in identical thematic fields ('nature', 'food', 'beverages') and their nuances of meaning (neutral and negative). In conclusion, the author points to the possibilities of a comparative study between Serbian and other Slavic languages, which would really give us important opinions about closeness/differences both within the Slavic linguistic world and within the South Slavic languages (in the Bulgarian language the meanings of the words hladan and holodniy are expressed by the word studen). The study also focuses on another important cultural problem that requires an interdisciplinary approach: the functioning of the said words as political metaphors and the specifically Russian semantics of the metaphor, denoted by the words holod 'cold', led 'ice', moroz 'frost'. The section ends with an article by A. Marinova, who supplements her own article from the previous volume with an illustration of Konstantin Miladinov's poetry, highlighting its language features. The text can be tied to the theme of the book by its comments on the poem "Grăk i Bulgarin" (Greek and Bulgarian), containing the Greek stereotype of the Bulgarian and the Bulgarian stereotype of the Greek, and the poem "Tăga za yug" (Sadness for the South), opposing the North (Russia) to the South (Bulgaria) and violating the mythological image of Russia in Bulgarian culture of the 19th century.

The second section of the book is entitled "Ideology: Cultural and Historical Contexts". P. Káša's article explores the formation of Slovak identity and directly addresses the problem of the boundaries of Slavism: "Between Hungarism and Slavism (Formation of the Collective Identity of Slovaks in the Age of Enlightenment of the 18th and 19th Century)". O. Timanova raises the question of the interaction of Slavic cultures through insufficiently investigated facts in her article "The Ancient Bulgarian Song about Orpheus and Its Translation into Russian by Rayko Zhinzifov (on Reciprocity in Slavic Literature)". The researcher illustrates the role of translation as an important factor in intercultural dialogue with the Russian translation of "The Ancient Bulgarian Song about Orpheus" from the collection of Stefan Verkovich by Raiko Zhinzifov (a Bulgarian Revival figure, a student in Moscow). Bearing in mind that the song is part of the Veda Slovena mystification, we can say that the study focuses on the process of creating an "imagined community" (according to Anderson). Timanova defines the genre of the work as a mythological tale, which allows her to analyse it through Prop's methodology of studying fairy tales. This analysis leads to the conclusion that the "Russian language is not just a mediator but a leader pointing to the path of intercultural dialogue through letters" (Tsanov, 2018, p. 112). The article by D. Chavdarova and R. Chavdarov discusses the concept of the sleeping people/ sleeping hero in Polish and Czech 
culture. Taking into account the diversity of the concept of the sleeping people, the authors discover its Slavic specificity expressed in the language with the appearance of the word buditel (a person who leads) in various Slavic languages. Along with the similarity of the concept of sleeping enslaved people in Slavic cultures, the study reveals the closeness of Czech and Polish cultures in the interpretation of the legend of the "sleeping knights" (in the context of the European Middle Ages), as well as the connotations specific to each of the two cultures concerning the concept of the sleeping people/ sleeping hero. D. Kristeva's text interprets the same concept, but in Russian culture: "The Sleeping Kingdom and Constants of Culture (Topicalization of the Concept in Russian Ideological Contexts)". The researcher's broad perspective encompasses the history of the concept of the sleeping kingdom: a folklore and mythological tradition, turning into an ideology of the Russian monarchy in the 18th century; how the concept functioned in Russian court Romanticism; the idea of sleep-slavery in the works of civic Romanticism, the revolutionary poetry of the 1950s and 1960s, and in émigré literature; thoughts on sleep as an element of the Russian mentality in Goncharov's Oblomov; the function of sleep in the socialist utopia of Chernyshevsky and Dostoevsky's short story The Crocodile contesting it; the ideological reading of Ostrovsky's fairy tale Snegurochka (The Snow Maiden) and the ballet based on it in the context of the King-Peacemaker. In conclusion, the researcher points to the contemporary use of the concept of sleeping nation in the political discourse, which suggests its constant character in Russian culture. A. Spasova analyses the idea of the Slavic origin of Bulgarians in historical and philological works during the Bulgarian Revival ("The Idea of the Slavic Origin of Bulgarians in Some Historical and Philological Works During the Revival"). In the historiographical works of Bulgarian Revival figures (from the late 18th to the late 19th century), the researcher discovered a mythopoetic historical narrative that finds Slavic traces in antiquity, Byzantine culture and the Huns in order to establish the ancient origins of the Bulgarians and to raise national self-esteem. B. Stoimenova considers the debate on the Slavic idea in the journals Den (Day) and Kambana (Bell) on the occasion of the Slavonic Council in Sofia in 1910: the clash between the apologists of the idea of the Slav Brotherhood and its critics, who make it problematic by giving examples of political conflicts between individual Slavic peoples (a debate which is still relevant today). The study is also valuable due to the publication of the texts in question in an appendix entitled "Slavonic Council in Sofia in 1910. Pros and Cons", which may be of help to researchers who would address the same problem. S. Tzanov's article "Bulgaria in the Eurasian Ideological Context of N. Trubetskoy" shows the clash between the linguist and the ideologist within Nikolay Trubetskoy - 
a world-class scholar and one of the founders of the Eurasian idea among Russian immigrants in Bulgaria. The author makes a critical assessment of Trubetskoy's ideas about the essence and role of the Old Bulgarian language (the distinction between the Old Church Slavonic and Old Bulgarian Church Slavonic languages, the emphasis on the Russian language, the denial of an independent Ukrainian language from the position of the Eurasian concept - "a dream for a new Russian Empire"). Such a controversy with the great scholar is of particular relevance to today's geopolitical reality. The problems of the Slav Brotherhood are also echoed in V. Kosik's article "The Image of the Enemy in the Slavic Mirror" which comments with journalistic pathos on manifestations of xenophobia within the Balkan Slavic community. By accepting the facts quoted, we can ask whether only the Balkan Slavs create an image of their own as an enemy. S. Sivriev refers to another important problem which is not related to the Slavic idea: the sovereignty of the Ruler in the description of Prince of Bulgaria Alexander Battenberg in a biblical code and the convergence with the image of a saint in the iconography in Marinov's book about Stefan Stambolov.

The third section of the book is devoted to the interpretation of the Slavonic idea in art (painting) and to cultural contacts between Slavic peoples in the field of theatre. N. Tsocheva analyses The Slav Epic by Czech artist Alphonse Mucha from 1912-1928 (his painting Bulgarian Tsar Simeon is featured on the book's cover) as a combination of myth and history for the establishment of the idea of Slavic unity and equal treatment of Slavic peoples (an important and contemporary idea opposing panSlavism). The researcher also shows the acceptance of The Slav Epic in Bulgaria in the 1920s, in the context of Spengler's idea of the Decline of the West, which opposes the Slavic mission of renewing Europe. The role of the Czechs in the history of Bulgarian culture is also discussed in an article by N. Patova: "Czech Director Jozef Shmaha (Josef Šmaha) and the First Steps of Bulgarian Theatre Establishing European Recognition". Examining the issue of the Czech director's cultural role in Bulgaria shows the value of communication among Slavic peoples in the cultural sphere without the Slavic idea being subordinated to politics and ideology.

Different perspectives on the boundaries of Slavdom and the cultural concepts of Slavism in the presented volumes give us reason to conclude that the study of these problems has no boundaries - not only because we can find new texts related to the subject, but also because our well-known, already discussed texts require a new reading in the new sociocultural and political situation.

Translation from Bulgarian Svetlana Nedelcheva 


\section{References}

Enchev, M. (Ed.). (2016). Limes Slavicus 1: Slavdom - boundaries of the community. Proceedings of the international scientific conference, Shumen, June 2015. Shumen: Konstantin Preslavsky University Press. Retrieved from http://shu.bg/ sites/default/files/izdaniq/Limes\%20slavicus_last.pdf

Kristeva, D. (Ed.). (2017). Limes Slavicus 2: Cultural concepts of Slavdom. Shumen: Konstantin Preslavsky University Press. Retrieved from http://shu.bg/sites/ default/files/izdaniq/limes2.pdf

Naĭdenova, D. (2017). „V imeto na Kiril i Metodiı”. Kirilo-metodievskata ideia i sotsialisticheskata propaganda. Slavia Meridionalis, 17, 1-25. https://doi. org/10.11649/sm.1349

Tsanov, S. (Ed.). (2018). Limes Slavicus 3: Cultural concepts of Slavdom. Shumen: Konstantin Preslavsky University Press. Retrieved from http://shu.bg/sites/ default/files/izdaniq/Limes3.pdf

\section{Limes Slavicus - Проект на Факултета за История}

и Теория на Литература в Шуменския Университет Константин Преславски (България)

Текстът представя трите книги от поредицата "Limes Slavicus" на факултета по хуманитарни науки при Шуменския университет „Епископ Константин Преславски“. Той дава представа за основните идеи на включените в изданията статии, но също така поставя въпроса за съдържанието на понятието „славянски културен концепт" и дискутира проблемите пред изследването на славянската културна общност (опасността от идеологизация, „славизирането“ на универсални концепти).

Ключови думи: културен концепт, славянска идея, славянство, граници на славянството.

\section{Limes Slavicus - Projekt Wydziału Historii i Teorii Literatury Uniwersytetu Konstantyna Presławskiego w Szumen (Bułgaria)}

Artykuł prezentuje trzy tomy serii „Limes Slavicus”, wydawanej przez Wydział Humanistyczny Uniwersytetu Biskupa Konstantyna Presławskiego w Szumen. W artykule zaprezentowano podstawowe tezy tekstów włą- 
czonych do serii, ale także poruszono problem zawartości semantycznej tytułowego pojęcia „słowiańskich konceptów kulturowych”, jak również kwestie wymagające ponownego zbadania ze strony słowiańskiej wspólnoty kulturowej: strach przed ideologizacją, slawizacja idei uniwersalnych.

Słowa kluczowe: koncept kulturowy, idea słowiańska, Słowiańszczyzna, granice Słowiańszczyzny.

Przekład z języka bułgarskiego

Jolanta Sujecka

\section{Note}

Dechka Chavdarova [Дечка Чавдарова], Full professor in the Department of History and Theory of Literature, Faculty of Humanities, Konstantin Preslavsky University of Shumen, Shumen.

d.tchavdarova@gmail.com

The preparation of the article was self-funded by the author.

No competing interests have been declared. 